\title{
Research on the Practice Teaching System of E-commerce based on "Professional- Employment-Entrepreneurship"
}

\author{
Hao Jin \\ Nanchang Normal University, Nanchang, Jiangxi,330032, China
}

\begin{abstract}
The construction of practical teaching system for e-commerce is the core issue of this professional research. Because the major belongs to the interdisciplinary subject, the construction of its practical teaching system is quite difficult, and it has become a problem that plagues the practical teaching of ecommerce. The relative scientific practice teaching system has not yet Forming, based on the three levels of "professional-employment-entrepreneurship", taking employment as the orientation, taking entrepreneurship as the highest goal, scientifically arranging its practical content, making e-commerce professional practice teaching more in line with social development needs.
\end{abstract}

KEYWORDS: E-Commerce; Practice Teaching System; Major-EmploymentEntrepreneurship

\section{Introduction}

With the rapid development of Internet information technology, e-commerce has increasingly become a major component of people's social and economic activities. In China alone, the scale of e-commerce market transactions in 2012 has exceeded 8.1 trillion yuan, and its development prospects are broad and its development potential is huge (Research Consulting Report, 2012). The rapid development of ecommerce in China has further aroused the sharp increase in the demand for ecommerce talents. In order to cater to this demand, since the Ministry of Education approved the first batch of 13 colleges and universities to establish e-commerce in 2001, more than 300 colleges and universities across the country have opened ecommerce majors. As we all know, the e-commerce major is a highly applied specialty. Therefore, its professional practice teaching plays a very important role in the talent training mode. However, in the past, e-commerce professional practice teaching activities often only stayed in the simulation operation stage of the laboratory. This "simulation practice teaching" is often too rigid, dogmatic, rigid, and its simulation environment cannot be related to the real banking, certification, logistics and other departments. Linked to the students to separate the understanding 
of e-commerce as a whole, thus ignoring the essence of e-commerce. As China's higher education enters the stage of popularization, the problem of college graduates facing employment difficulties is increasingly prominent. Entrepreneurship education is bound to receive attention when solving the problem of college students' employment difficulties. Encouraging college students to start their own businesses after graduation is undoubtedly an effective measure to alleviate the current difficult employment problems. The report of the 18th National Congress of the Communist Party of China clearly pointed out that it is necessary to "promote employment through entrepreneurship to promote employment development strategy". By vigorously carrying out entrepreneurship education to change the traditional talent training objectives, not only can students develop professional knowledge and skills, but also focus on cultivating students to master entrepreneurial knowledge and skills, improve their entrepreneurial quality and ability, and make college graduates not only become good The quality of job seekers, but also become the creators of new jobs, and the e-commerce's openness, convenience, economy and other advantages also make college students start their own businesses. Therefore, if entrepreneurship education, innovative education and e-commerce professional practice teaching can be organically combined, ecommerce entrepreneurship education as the main line, re-establish the e-commerce professional practice teaching system, cultivate students' entrepreneurial awareness, and enhance students' entrepreneurial ability, not only It can guarantee the effective implementation of e-commerce practice teaching, fundamentally change the current e-commerce professional practice teaching "real tricks and fakes", continuously improve students' professional application ability; more able to meet the rapid development of China's e-commerce to applied electronics The urgent need of business talents, and give full play to the advantages of e-commerce, advocate selfemployment among college students, and ease the employment pressure of college graduates.

\section{At Present, China's Colleges And Universities E-Commerce Professional Practice Teaching System}

E-commerce awareness level. This level of practical teaching is mainly based on direct visits to e-commerce companies, website observations, case studies, etc., so that students initially form a perceptual understanding of e-commerce and enterprise information, thus laying a good foundation for students to learn professional courses.

E-commerce application level. This level of practical teaching mainly allows students or their own team to organize e-commerce operations by organizing data and applying e-commerce teaching and operation software; or allowing students to apply appropriate programming languages and development tools to plan and design personalized e-commerce. However, the current degree of simulation of e-commerce teaching and operation software is mostly simple and rough, just a simple simulation of a business operation mode, its simulation environment cannot be linked with the real banking, certification, logistics and other departments, it is difficult to truly reflect e-commerce The difficulties encountered in the business operation process 
and operation process are lack of openness. In addition, the e-commerce website system programming teaching practice is similar to other professional programs such as computer science and technology software practice teaching; it is difficult to reflect the characteristics of e-commerce professional, but also enables students to separate the understanding of e-commerce as a whole, thus neglecting The essence of e-commerce.

E-commerce actual combat level. E-commerce practical level teaching is mainly aimed at students to start a business, voluntarily set up a team, systematically plan and improve e-commerce enterprise development strategy and operation plan, and carry out a series of simulation market business activities. However, this level of teaching tends to be in the form. For example, most students only work to complete homework, lack autonomy, and will not actually put e-commerce business plans into practice. There is also a lack of corresponding education in colleges and universities. It can be seen that the practical teaching system of e-commerce in China's colleges and universities still needs to be perfected, and there is no systematic entrepreneurial education theory and training system. It is urgent to continuously improve and deepen a new open-based entrepreneurship education in practice.

\section{The "Professional-Employment-Entrepreneurship" E-Commerce Professional Practice Teaching System}

The overall idea of formulating e-commerce practice teaching plan is to implement the spirit of entrepreneurial instruction in relevant documents of the Ministry of Education. With high-quality employment as the core and entrepreneurship as the highest goal, social practice projects are integrated into curriculum teaching, experimental teaching, and scientific and technological activities. Improve students' practical, communication, innovative and social adaptability. The practice teaching link of e-commerce is composed of modules such as course experiment, training, curriculum design, scientific and technological innovation activities, social practice, professional cognitive internship, management internship, production internship, graduation internship, graduation design, etc. The functions between the modules are clear. Complement each other.

Course training: Arranged in the class, completed in the training, mainly verification experiments. All kinds of internships and curriculum design: There will be practice weeks in each semester, and it is more appropriate to arrange in the training week, in the practice base and training room inside and outside the school. Science and technology innovation activities: including "Challenge Cup", college students' innovative skills competition and national e-commerce competition, etc., arranged outside the classroom and holidays, the main target is a more professional part of the students, can be carried out in the training room and the practice base. Social Practice: At the end of the term, students are arranged to conduct social research on a topic during the holidays. Graduation design: Conducted in the sixth semester, in the training room, internship base or internship unit. 
E-commerce is a highly applied specialty. It is important not only to emphasize theoretical teaching, but also to cultivate students' innovative ability and practical ability training. In the teaching plan, the proportion of practical teaching should be increased, and the content of practical teaching should be rich to form a practical teaching content system of e-commerce professional at the level of professional, employment and entrepreneurship. The structure is shown in Figure 2. The practical teaching of e-commerce is in the whole process of professional education. Among them, course training, internship and social practice help students to transform the theoretical knowledge of e-commerce professional into application; the practice links such as management internship and production internship make students more familiar with the workflow; Disciplinary competitions, professional positions and skills training can help students solve practical problems. Entrepreneurial education, entrepreneurial practice, social services and other practical aspects can enhance students' entrepreneurial ability. The course training is completed in the training room. It is a practical teaching link for the knowledge points or skill points of the course. Through the course training, the students can deeply understand and master the content of theoretical knowledge and improve the students' practical ability. Production internships and management internships are students' internships outside the school. Students enter e-commerce enterprises, experience the operation mode of e-commerce companies, business website operations and website design techniques, so that students can rise to rational understanding and employment in the field experience. The post has a clear understanding and provides a case for student entrepreneurship. Graduation internship is a springboard for student employment and entrepreneurship. Through the springboard, students can better connect with the society. For example, when completing a company's e-commerce system planning and design during graduation internship, it is necessary to visit the industrial and commercial enterprise or trade marketing department. It is very familiar with the actual operation of all aspects of trade marketing, knowing the business process and basic operational skills, and fully grasping the operation of the enterprise information flow, logistics and capital flow. Only in this way can the graduation internship project be completed. Entrepreneurship Education and Entrepreneurial Practice: Entrepreneurship education is the main way to cultivate students' ability to innovate and start a business. It is possible to open up entrepreneurial courses and entrepreneurial lectures to popularize entrepreneurial knowledge, so that some students can take the lead in starting a business, thus driving more students to start a business. It is possible to establish a business park to provide students with entrepreneurial training venues and encourage students to e-commerce.

Monitoring the whole process of practical teaching objectives, teaching content, implementation process, teaching assessment, etc. is the guarantee to ensure the effective implementation of practical teaching programs and systems. It can establish a practical teaching quality monitoring and guarantee system consisting of five subsystems: practical teaching target system, practical teaching quality standard system, and practical teaching operation system, practical teaching quality monitoring system and teaching support system. After establishing the training objectives and practical teaching plans for e-commerce professionals, it is necessary to form a practical teaching target system, formulate work regulations for practical 
teaching, and study and formulates various course exercises on the basis of the established e-commerce professional practice teaching programs. The syllabus and quality standards of practice links such as internships, curriculum design, graduation design, etc., establish a system of practical teaching quality standards. The practice teaching operation system is the key link in the practice teaching system guarantee; it is necessary to strengthen the record of the practice teaching process, pay attention to every detail of the teaching process, and guarantee the quality of the practice teaching operation. Through the backbone teachers of external e-commerce enterprises as part-time teachers, enrich the team of practical teaching teachers. The teaching support system provides a reliable guarantee for improving the quality of practical teaching. The practice teaching quality monitoring system consists of three parts: information collection, analysis and evaluation and feedback adjustment. It conducts a comprehensive evaluation of practical teaching and ensures the practical teaching tasks and quality.

\section{The Problem of Constructing The Practice Teaching System of E-Commerce Professional Needs Attention}

The construction of the practical teaching system of e-commerce should be guided by the needs of the industry and establish the goal of training practical teaching talents. Grasping the development of the industry and specific needs in a timely manner, and dynamically adjusting the training objectives of professional practice teaching personnel is the basis for the construction of e-commerce professional construction and practical teaching system based on innovation and entrepreneurship education. Cultivate students to become practical talents with solid professional knowledge, skilled professional skills, innovative entrepreneurship and innovative entrepreneurship, and can actively adapt to the development needs of the e-commerce industry.

When carrying out the top-level design of innovation and entrepreneurship education, colleges and universities should integrate innovation and entrepreneurship education with practical teaching system, and run through the whole process of e-commerce professional talent training, and gradually form "innovation and entrepreneurship teaching-innovation and entrepreneurship simulation-innovation and entrepreneurship practice" The benign interactive teaching model promotes the rapid transformation of innovation and entrepreneurial knowledge and e-commerce expertise into practical ability.

Relying on the school's innovation and entrepreneurship practice base, students will come out of the theory through practice and bring together existing knowledge and technology to become a platform for college students' scientific and technological cooperation and innovation and entrepreneurship services. 2. Relying on the cooperation between the off-campus innovation and entrepreneurship incubation base and various enterprises, we will build a simulation innovation and entrepreneurship platform, so that more students can actually participate in the specific management and operation of the enterprise, and improve their ability to innovate and start their own businesses. 3. Strengthen multi-modal school-enterprise 
cooperation (such as enterprise training practice, order training, etc.), so that students can actively participate in the specific practice of a certain period of time in the cooperative enterprise, allowing students to learn e-commerce operations from actual combat. The knowledge related to logistics and distribution is transformed into the ability to familiarize with the operational procedures of various positions in e-commerce enterprises, to feel the corporate culture, and to lay the foundation for future job hunting and entrepreneurship. Students with outstanding performances in training and internships will also be preferred by enterprises, which will solve the problem of shortage of e-commerce professionals and benefit universities, enterprises and students. 4. Strengthen the specific practice and classification guidance of simulated innovation and entrepreneurship. The time for students to participate in innovation and entrepreneurship is regarded as the time for participating in practical teaching, and is included in the relevant teaching practice credits. The relevant competition or entity achievements obtained by students' innovation and entrepreneurship can be graduated. Design or graduation thesis is organically combined.

\section{Conclusion}

Although the research on the practical teaching system based on entrepreneurship education in our country has achieved certain theoretical and practical results, in order to further adapt to the requirements of entrepreneurship education for talent training, further improvement and optimization are needed. Based on the e-commerce entrepreneurship education, this paper puts forward the ecommerce professional practice teaching system based on entrepreneurship education. It is hoped that through the improvement of the practice teaching of entrepreneurship education, the new characteristics and new advantages of ecommerce professionals training will be taken out.

\section{References}

[1] Li Hua(2010). Discussion on the reform of e-commerce professional education driven by online entrepreneurship. SME Management and Technology, vol.24, p.169.

[2] Chen Xianghua, Wang Kefu(2008). Construction of Practical Teaching System for E-commerce Majors in Colleges and Universities Based on Entrepreneurship Education. E-commerce, (11): 88-91.

[3] Feng Wei(2013). Research on the "five in one" practical teaching system of ecommerce. Education and Teaching Forum, (14): 229-231.

[4] Zhu Wenya(2012). Research on the Practice Teaching System of E-Commerce Based on "Professional - Employment - Entrepreneurship" [J]. China Higher Education Research, Vol. 2, p.107-110.

[5] Zhang Chunling, Liu Zunfeng(2012). Research on College Students' Entrepreneurship Education Based on E-commerce Platform [J]. Education and Occupation,Vol.3, p.93-94. 